\title{
Hukum Keluarga Islam di Indonesia: dari Orde Lama hingga Orde Reformasi
}

\author{
Ahmad Rajafi
}

\begin{abstract}
Islamic Family Law in Indonesia: From Old to Reformation Order. Historically, the rule of Islamic family law existed and has been practiced since the early arrival of Islam in the archipelago. This is indicated by the phenomenon of massive application of fiqh madzhab asy-syafi'iyyah in the colonialization era.. After the day of Independence, the efforts to established Islamic family law through political institutions has begun, starting from the old order era until the reform era. The reform movement grew stronger mainly after CLD-KHI was echoed to make KHI ( Collection of Islamic Law) a new Marriage Act. Unfortunately, this movement received a negative response from a number of Islamic organizations; so the plan was canceled by the Government. Nevertheless, the struggles between liberal and conservative-fundamentalist Islamic thought still continue to this day.
\end{abstract}

Keywords: renewal movement, family law of Islam, CLD-KHI, Indonesia

Abstrak: Hukum Keluarga Islam di Indonesia: dari Orde Lama hingga Orde Reformasi. Secara historis, aturan tentang hukum keluarga Islam telah ada dan dipraktekkan di Indonesia sejak awal kedatangan Islam di bumi Nusantara. Hal ini ditunjukkan dengan adanya fenomena penerapan fikih madzhab al-syâfi'iyyah secara massif di masa lampau. Setelah NKRI berdiri, pembaruan hukum keluarga Islam melalui lembaga politik dimulai sejak era orde lama hingga era reformasi. Gerakan pembaruan tersebut semakin menguat setelah CLD-KHI dikumandangkan untuk menjadikan KHI sebagai UU Perkawinan yang baru. Sayangnya, gerakan ini mendapat respon negatif dari beberapa ormas Islam sehingga rencana tersebut dibatalkan oleh Pemerintah. Meskipun demikian, pergumulan antara pemikiran Islam liberal dan fundamentalis-konservatif masih terus berlanjut hingga saat ini.

Kata Kunci: gerakan pembaruan, hukum keluarga Islam, CLD-KHI, Indonesia

Institut Agama Islam Negeri Manado

Jl. Manguni, Malendeng, Tikala, Kota Manado, Sulawesi Utara

E-mail: ahmad.rajafi@iain-manado.ac.id 


\section{Pendahuluan}

Indonesia adalah negara majemuk dengan jumlah umat Islam sebagai kelompok mayoritas. ${ }^{1}$ Implikasinya adalah, dibutuhkan aturanaturan hukum yang mengatur kebutuhan hajat hidup mereka, seperti perkawinan, pelaksanaan haji, pendistribusian zakat, pengelolaan wakaf, ekonomi Islam, dan lainnya. Secara politis, kebutuhan hukum tersebut di masyarakat sebagai bentuk eksistensi agama (hukum Islam) dalam "percaturan" politik hukum di Indonesia, di luar hukum Belanda dan hukum Adat.

Kreasi hukum tersebut dalam konteks hukum keluarga adalah lahirnya Undang-undang No. 1 Tahun 1974 tentang Perkawinan (selanjutnya disebut UU Perkawinan) dan Instruksi Presiden Nomor 1 Tahun 1991 Tentang Kompilasi Hukum Islam (kemudian disebut KHI) berdasarkan penelitian besar para ahli di Indonesia baik akademisi, ulama dan birokrat Muslim, dengan berbagai kelebihan dan kekurangannya. ${ }^{2}$ Salah satu produk hukum yang dirasa bertentangan dengan fikih adalah, diperbolehkannya istri untuk menuntut dan mengajukan cerai ke Pengadilan Agama. Bagi para ulama, istri yang meminta cerai tanpa sebab yang tegas dan jelas adalah bukti kedurhakaan dan dosa besar. ${ }^{3}$

${ }^{1}$ Menurut publikasi BPS pada bulan Agustus 2010, jumlah penduduk Indonesia berdasarkan hasil sensus adalah sebanyak 237.556.363 orang, yang terdiri dari 119.507.580 laki-laki dan 118.048.783 perempuan, dengan tingkat laju pertumbuhan rata-rata sebesar 1,4\% per tahun. Sementara distribusi menurut agamanya, di tahun 2010, kira-kira 85,1\% dari penduduk Indonesia adalah pemeluk Islam, 9,2\% Protestan, 3,5\% Katolik, 1,8\% Hindu, dan 0,4\% Buddha. Lihat web-nya di www.bps.go.id.

2 Terkait pemikiran akademisi terhadap UU No 1 tahun 1974 dan KHI dapat dilihat dalam karya P. H. Sidharta. "Undang-Undang Perkawinan Ditinjau dari Segi Hukum Antar Tata Hukum pada Dewasa Ini.” Jurnal Hukum \& Pembangunan 22, no. 4 (1992): 334-353. Muhammad Hasbi. "Studi Komparatif Antara Hukum Islam dan Hukum Positif Undang-Undang Perkawinan No 1 Tahun 1974 Tentang Batas Ketaatan Isteri Terhadap Suami.” PhD diss., Universitas Muhammadiyah Surakarta, 2013. Fatroyah Asr Himsyah. "Batas Usia Perkawinan Menurut pasal 7 Undang-Undang no. 1 tahun 1974 Perspektif Undang-Undang No. 23 Tahun 2002 Tentang Perlindungan Anak." PhD diss., Universitas Islam Negeri Maulana Malik Ibrahim Malang, 2011. Juliana Pretty Sanger. "Akibat Hukum Perkawinan Yang Sah Didasarkan Pada Pasal 2 UU. Nomor 1 Tahun 1974 Tentang Perkawinan.” Lex Administratum 3, no. 6 (2015). Marzuki Wahid. "Counter Legal Draft Kompilasi Hukum Islam (CLD-KHI) dalam Perspektif Politik Hukum di Indonesia." In 4th Annual Islamic Studies Postgraduate Conference, The University of Melbourne, pp. 17-18. 2008.

${ }^{3}$ Semangat pemikiran seperti ini didasarkan kepada hadis nabi Muhammad Saw: "Bagi seorang wanita yang meminta cerai kepada suaminya tanpa alasan yang kuat maka haram baginya mencium 
Keterangan di atas menunjukkan bahwa stagnasi dalam berpikir akan melahirkan produk hukum yang lemah. Untuk itu, keseriusan dalam memformulasi kembali pemikiran fikih tentang hukum keluarga Islam di Indonesia merupakan keniscayaan yang harus ditindaklanjuti. ${ }^{4}$ Ada beberapa produk hukum yang dirasa tidak responsif, seperti status wali dalam perkawinan yang dianggap bias gender, nikah siri atas nama agama, pengakuan anak hasil nikah siri, dan lainnya, yang menggugah para ahli pada era selanjutnya untuk menggugat UU Perkawinan dan KHI melalui semangat evaluasi dan revisi.

Dialektika pembaruan hukum keluarga di Indonesia tersebut seharusnya terus berprogres dan tidak berhenti di satu masa saja, karena hukum sejatinya selalu bergerak dalam menghadirkan kemaslahatan di dunia dan di akhirat bagi umat manusia, sehingga kemungkinan merevisi produk hukum selalu ada sejalan dengan perubahan waktu, tempat dan keadaan. Meskipun demikian, sejatinya pembaruan hukum tidak bersifat skriptualistik dan menegasi konteks-konteks lain yang lebih kompleks, khususnya pada ranah HAM dan kesetaraan gender. Oleh karenanya melalui tulisan ini, akan dipaparkan tentang pergumulan politik hukum keluarga Islam di Indonesia dari orde lama hingga reformasi.

udara surga." Lihat Muhammad bin Hibban, Shahih Ibnu Hibban, vol. 9 (Bayrût: Mu’assasah alRasalah, 1993), h. 490.

${ }^{4}$ Politik hukum keluarga dalam perjalanan panjangnya telah dituangkan di berbagai karya ilmiah di antaranya Tengku Erwinsyahbana. "Perspektif Hukum Perkawinan Antar Agama yang Berkeadilan Dikaitkan dengan Politik Hukum Perkawinan Indonesia dalam Rangka Pembangunan Hukum Keluarga Nasional.” Indonesian Journal of Dialectics 2, no. 2 (2012). Marzuki Wahid. "Pembaruan Hukum Keluarga Islam di Indonesia Paska Orde Baru: Studi Politik Hukum atas Counter Legal Draft Kompilasi Hukum Islam [Renewal of Islamic Family Law in Post at New Order Indonesia: Legal-Political Study On Counter Legal Draft of the Compilation of Islamic Law]." In 4th Annual Islamic Studies Postgraduate Conference, Melbourne, pp. 17-18. 2008. Tengku Erwinsyahbana. "Sistem Hukum Perkawinan pada Negara Hukum Berdasarkan Pancasila." Jurnal Ilmu Hukum 3, no. 01 (2013). Ninik Rahayu. "Politik Hukum Itsbat Nikah." Musãwa Jurnal Studi Gender dan Islam 12, no. 2 (2016): 279-294. M Sularno. "Dinamika Hukum Islam Bidang Keluarga di Indonesia." Al-Mawarid 18 (2008). 


\section{Sejarah Gerakan Pembaruan}

\section{Era Orde Lama}

Gerakan Islam pada era Orde Lama diawali dengan kesepakatan bersama tentang Pancasila dan lahirnya Departemen Agama. Akan tetapi ketentuan hukum keluarga di era itu masih mengikuti hukum peninggalan kolonial Belanda, di mana (1) bagi orang-orang Indonesia asli berlaku hukum adat; (2) bagi orang-orang Indonesia asli beragama Islam berlaku hukum perkawinan Islam; (3) bagi orang-orang Indonesia asli yang beragama Kristen (Jawa, Minahasa dan Ambon) berlaku Ordonansi Perkawinan Kristen (Huwelijks Ordonnantie Christen Indonesiaers atau HOCI); (4) bagi warga negara keturunan Eropa dan Cina berlaku Kitab undang-undang Hukum Perdata (Burgerlijk Wetboek atau BW); dan (5) bagi perkawinan campuran berlaku peraturan perkawinan campuran (Staatsblad 1898 No. 158) atau Regeling op de Gemengde Huwelijken. ${ }^{5}$

Keadaan seperti itu pada akhirnya mendapatkan perhatian khusus dari pemerintah pada tahun 1946, dengan menetapkan Undang-Undang No. 22 Tahun 1946 tentang Pencatatan Nikah, Talak dan Rujuk yang berlaku untuk daerah Jawa dan Madura, kemudian oleh Pemerintah Darurat RI di Sumatera, UU tersebut dinyatakan berlaku juga untuk seluruh wilayah Sumatera. ${ }^{6}$ Untuk menerapkan UU tersebut, negara menerbitkan Instruksi Menteri Agama No. 4 Tahun 1947 tentang penunjukan Pegawai Pencatat Nikah (PPN), dengan tugas berusaha untuk mencegah perkawinan anak yang belum cukup umur, menerangkan kewajiban-kewajiban suami yang berpoligami, mengusahakan perdamaian bagi pasangan yang bermasalah, menjelaskan bekas suami terhadap bekas istri dan anak-anaknya apabila terpaksa bercerai, menjelaskan tentang masa iddah, dan mengusahakan pasangan yang bercerai untuk rujuk kembali. ${ }^{7}$ Ketentuan tersebut berlaku hingga tahun 1954, karena pada

5 Wirjono Prodjodikoro, Hukum Perkawinan di Indonesia, 8th ed. (Bandung: Sumur, 1984), h. 14-15.

${ }^{6}$ Nani Soewondo, Kedudukan Wanita Indonesia dalam Hukum dan Masyarakat, 2nd ed. (Jakarta: Timun Mas, 1968), h. 96.

${ }^{7}$ Nani Soewondo, Kedudukan Wanita Indonesia dalam Hukum dan Masyarakat, h. 78-79. 
tahun itu pemerintah akhirnya mengeluarkan UU No. 32 Tahun 1954, sebagai acuan atas pemberlakuan UU No. 22 Tahun 1946 untuk seluruh wilayah Indonesia.

Perjalanan semangat pembaruan hukum keluarga di Indonesia ternyata tidak berhenti di tempat, karena pada bulan Agustus 1950, Front Wanita dalam Parlemen, mendesak agar Pemerintah meninjau kembali peraturan perkawinan dan menyusun rencana undang-undang perkawinan secara permanen. Konsekuensinya, pada akhir tahun 1950, melalui Surat Perintah Menteri Agama No. B/2/4299 tertanggal 1 Oktober 1950 dibentuklah Panitia Penyelidik Peraturan dan Hukum Perkawinan, Talak dan Rujuk bagi umat Islam. ${ }^{8}$ Panitia tersebut terdiri dari orangorang yang dianggap berkompeten pada keilmuan hukum umum, hukum Islam dan Kristen dari berbagai aliran, yang diketuai oleh Tengku Hasan, dengan tugas utama menyusun Rancangan Undang-Undang (selanjutnya disebut RUU) Perkawinan yang dapat menampung semua kenyataan hukum yang hidup dan berkembang dalam masyarakat pada waktu itu.

Pada tahun 1952, panitia akhirnya mampu untuk merampungkan pekerjaan mereka, dengan menelurkan konsep RUU yang berlaku untuk semua golongan dan agama, beserta peraturan-peraturan khusus yang mengatur golongan agama masing-masing. Pada tanggal 1 Desember 1952, panitia menyampaikan RUU Perkawinan Umum kepada semua organisasi pusat dan lokal dengan permintaan agar masing-masing anggota dapat memberikan pendapat atau pandangannya terhadap RUU tersebut hingga 1 Februari $1953 .{ }^{10}$ Rumusannya adalah:

a. Perkawinan harus didasarkan kemauan bulat dari kedua belah pihak, untuk mencegah kawin paksaan ditetapkan batas-batas umur 18 bagi laki-laki dan 15 bagi perempuan.

b. Suami isteri mempunyai hak dan kedudukan yang seimbang dalam kehidupan rumah tangga dan pergaulan hidup bersama dalam masyarakat.

${ }^{8}$ Asro Sosroatmodjo and A. Wasit Aulawi, Hukum Perkawinan di Indonesia (Jakarta: Bulan Bintang, 1978), h. 9.

${ }^{9}$ Nani Soewondo, Kedudukan Wanita Indonesia dalam Hukum dan Masyarakat, h. 176.

${ }^{10}$ Nani Soewondo, Kedudukan Wanita Indonesia dalam Hukum dan Masyarakat, h. 177. 
c. Poligami diizinkan bila diperbolehkan oleh hukum agama yang berlaku bagi orang yang bersangkutan dan diatur sedemikian hingga dapat memenuhi syarat keadilan.

d. Harta bawaan dan harta yang diperoleh selama perkawinan menjadi milik bersama.

e. Perceraian diatur dengan keputusan Pengadilan Negeri, berdasarkan alasan-alasan yang tertentu, mengenai talak dan rujuk diatur dalam peraturan Hukum Islam.

f. Kedudukan anak sah atau tidak, pengakuan anak, mengangkat dan mengesahkan anak, hak dan kewajiban orang tua terhadap anak, pencabutan kekuasaan orang tua dan perwalian. ${ }^{11}$

Setelah penyampaian RUU di atas, maka pada tanggal 24 April 1953, panitia mengadakan hearing (dengar pendapat) dengan organisasiorganisasi kemasyarakatan Islam, dan memutuskan di bulan Mei-nya untuk menyusun Undang-Undang Perkawinan sesuai sistem hukum yang berlaku, yakni:

a. Undang-Undang Pokok yang berisi semua peraturan yang berlaku bagi umum bersama-sama (uniform), dengan tidak menyinggung agama.

b. Undang-Undang Organik, yang mengatur soal perkawinan menurut agama masing-masing, yaitu bagi golongan Islam, Kristen Katolik, dan golongan Kristen Protestan.

c. Undang-Undang untuk golongan netral, yaitu yang tidak termasuk suatu golongan agama. ${ }^{12}$

Lalu pada tahun 1954, akhirnya panitia berhasil membuat RUU Perkawinan yang kemudian disampaikan oleh Menteri Agama pada Sidang Kabinet di akhir bulan September 1957 dengan penjelasan masih akan ada perubahan susulan. Namun hingga awal tahun 1958, tidak ada sama sekali gerakan dari pemerintah dalam melanjutkan kerja di atas, sehingga menjadikan "gerah" para angota parlemen dari golongan wanita

${ }^{11}$ Nani Soewondo, Kedudukan Wanita Indonesia dalam Hukum dan Masyarakat, h. 178-79.

${ }^{12}$ T. Jafizham, Persentuhan Hukum di Indonesia dengan Hukum Perkawinan Islam (Medan: Mestika, 1977), h. 180. 
yang dipimpin oleh Soemari, kemudian berinisiatif untuk mengajukan rancangan undang-undang perkawinan di tahun 1958 dengan salah satu usulannya yang kemudian mendapatkan reaksi keras dari pemerintah dan masyarakat, yakni menetapkan asas monogami sebagai asas perkawinan di Indonesia yang bersifat absolut.

Setelah pemerintah ikut menanggapi permasalahan itu, perjalanan rencana legislasi hukum perkawinan Islam kembali berhenti di tengah jalan. Akibat munculnya penentangan dari internal Islam khususnya kelompok tradisionalis yang beranggapan bahwa aturan syari'at yang ada sesunguhnya telah mencakup semua ketentuan itu, sehingga tidak diperlukan lagi pengundangan hukum keluarga Islam di Indonesia. Bagi mereka, peraturan-peraturan yang telah diberikan Tuhan, sebagaimana yang telah diwahyukan secara cermat dalam syari'at, diperuntukkan untuk segala zaman dan negara. Hasilnya, semua bahan-bahan baru tersebut, yang dihasilkan dari tahun 1953 hingga 1958, tidak pernah lagi dibahas kelanjutannya oleh pemerintah dan parlemen. ${ }^{13}$ Adapun usulan Soemari dan rekan-rekannya, di bulan oktober 1959 akhirnya ditarik kembali akibat perlawanan yang tajam dari anggota DPR dari partai Islam, khususnya pada ide monogami di dalam perkawinan. Sehingga tidak ada satu pun produk hukum Islam di bidang hukum keluarga yang terkodifikasi atau terlegislasi yang dapat menjadi rujukan utama umat Islam Indonesia.

\section{Era Orde Baru}

Politik hukum berusaha membuat kaidah-kaidah yang akan menentukan bagaimana seharusnya manusia bertindak. Politik hukum menyelidiki perubahan-perubahan apa yang harus diadakan dalam hukum yang sekarang berlaku supaya menjadi sesuai dengan sociale werkelijkheid (kenyataan sosial). Dalam membahas politik hukum maka yang dimaksud adalah keadaan yang berlaku pada waktu sekarang di Indonesia sesuai dengan asas pertimbangan (hirarki ) hukum itu sendiri,

${ }^{13}$ Mengenai pergulatan politik di era Orde Lama ketika merumuskan RUU Perkawinan Islam, dapat dirujuk dalam J. Prins, Hukum Perkawinan di Indonesia, trans. G.A. Ticoalu (Jakarta: Ghalia Indonesia, 1982), h. 1920. 
atau dengan terminologi Logemen, sebagai hukum yang berlaku di sini dan kini. ${ }^{14}$

Sedangkan tugas dari politik hukum itu sendiri ialah untuk meneliti perubahan-perubahan mana yang perlu diadakan terhadap hukum yang ada agar memenuhi kebutuhan-kebutuhan baru di dalam kehidupan masyarakat. Adanya politik hukum menunjukkan eksistensi politik hukum negara tertentu, begitu pula sebaliknya, eksistensi politik hukum dari negara tertentu. ${ }^{15}$

Sejarah mencatat bahwa politik hukum era Orde Baru menuju pembentukan UU No. 1 Tahun 1974 telah mengalami perjalanan yang begitu panjang dan rumit seperti yang terjadi di era Orde Lama. Diawali melalui sidang Parlemen baru DPR-GR 1967-1971 yang mendapatkan pengajuan RUU Perkawinan dari dua departemen, yakni RUU tentang Perkawinan Umat Islam yang diajukan oleh Departemen Agama di bulan Mei 1967, dan RUU tentang ketentuan-ketentuan pokok perkawinan yang diajukan oleh Departemen Kehakiman di bulan September 1968. Namun, karena adanya pengajuan khusus RUU tentang Perkawinan Islam dari Departemen Agama, maka muncullah penolakan yang keras dari Fraksi Katolik yang anggotanya 8 berbanding 500 (8:500), dengan rasionalisasi:

“...tjara pengaturan perkawinan sebagaimana ditentukan oleh kedua Rantjangan Undang-undang adalah tidak sesuai dengan hakekat Negara Pantjasila, hal jang demikian berarti bahwa ada perubahan dasar Negara. Negara tidak lagi berdasarkan Pantjasila tetapi berdasarkan agama; hal di mana tjotjok dengan prinsip jang terkandung dalam Piagam Djakarta." ${ }^{16}$

Adu argumentasi antara kelompok Islam dengan Kristen ternyata terus berlangsung hingga pergantian anggota parlemen pasca pemilu

${ }^{14}$ M. Yasin al Arif, "Politik Hukum Calon Tunggal dalam Putusan Mahkamah Konstitusi dan Implikasinya Terhadap Sistem Pilkada Serentak”, Jurnal Yuridis 3, no. 2, (2016), h. 214.

${ }^{15}$ Bagus Anwar Hidayatullah, "Politik Hukum Sistem Pemilu Legislatif dan Presiden Tahun 2009 dan 2014 dalam Putusan Mahkamah Konstitusi”, Jurnal Hukum Ius Quia Iustum 21, no. 4, (2014), Yogyakarta: Fakultas Hukum Universitas Islam Indonesia, h. 564.

${ }_{16}$ Pokok-pokok pikiran mereka secara lengkap dimuat dalam harian Operasi, April 14, 1969. Lihat H. M. Rasjadi, Kasus RUU Perkawinan dalam Hubungan Islam dan Kristen (Jakarta: Bulan Bintang, 1974), h. 34. 
legislatif di tahun 1971. Pada bulan Juli 1973, Pemerintah kembali memasukkan RUU Perkawinan yang baru ke DPR hasil Pemilu 1971 tersebut dengan menarik RUU sebelumnya yang telah diajukan oleh Departemen Agama pada tahun 1967 dan Departemen Kehakiman tahun 1968-nya. ${ }^{17}$ Namun ternyata penolakan atas RUU tersebut terjadi dari internal Islam sendiri, karena ada beberapa pasal di dalam RUU yang dianggap bertentangan dengan Islam, Pancasila dan UUD 1945. Ketentuan-ketentuan atau pasal-pasal di dalam RUU yang dinyatakan bertentangan dengan hukum Islam adalah: ${ }^{18}$

a. Sahnya perkawinan (Pasal 2 ayat 1), di mana menurut mereka sahnya perkawinan hanya jika terpenuhinya rukun di dalam perkawinan, seperti ijab-kabul yang dilakukan oleh kedua mempelai dan disaksikan oleh dua orang saksi, dan bukannya pencatatan perkawinan.

b. Larangan kawin karena hubungan anak angkat (Pasal 8 c) dan larangan kawin untuk ketiga kalinya bagi suami istri yang pernah bercerai dua kali (Pasal 10). Kedua ketentuan ini tidaklah sesuai dengan larangan perkawinan yang diisyaratkan oleh Allah di dalam Q.s. an-Nisa' [4] ayat 22 samapi 24.

c. Perbedaan agama bukan merupakan penghalang perkawinan (Pasal 11). Di dalam Islam perbedaan agama menjadi unsur penghalang utama dalam perkawinan sesuai Q.s. al-Baqarah [2] ayat 221 dan Q.s. al-Mumtahanah [60] ayat 10 .

d. Jangka waktu tunggu bagi janda untuk dapat kawin lagi adalah 306 hari (Pasal 12). Hal ini bertentangan dengan aturan 'iddah yang dijelaskan di dalam Islam, di mana jika wanita janda kerena cerai masa tunggunya selam tiga quru' (suci atau bersih), pasca melahirkan jika hamil, dan 4 bulan 10 hari bagi yang ditinggal mati suami.

${ }^{17}$ Lihat "Amanat Presiden No. R.02/P.U/VII/1973 Perihal RUU Tentang Perkawinan," July 31, 1973.

18 Taufiqurrohman Syahuri, Legislasi Hukum Perkawinan di Indonesia: Pro-Kontra Pembentukannya Hingga Putusan Mahkamah Konstitusi (Jakarta: Kencana, 2013), h. 108-15. 
Polemik di atas semakin diperkeruh dengan anggapan bahwa lahirnya RUU Perkawinan semata-mata untuk terus menghidupkan teori receptie Snouck Hurgronje dengan tujuan utama menghapus hukum Islam di Indonesia dengan cara menyandarkan keberlakuan hukum Islam ke dalam hukum adat, ${ }^{19}$ dan hukum Barat ${ }^{20}$ melalui sub materi "pencatatan perkawinan". Pada akhirnya melalui lobi-lobi politik antara kelompok Islam yang diwakili oleh Partai Persatuan Pembangunan (selanjutnya disebut PPP) dan pemerintah yang diwakili oleh kelompok militer, dicapailah sebuah kesepakatan penghapusan beberapa pasal tentang aturan-aturan yang telah menjadi pemicu protes dan dipandang bertentangan dengan prinsip-prinsip Islam, dan pada tanggal 22 Desember 1973 DPR mengesahkan RUU tersebut sebagai UU, dan ditandatanganioleh Presiden dalam Lembaran Negara No. 1 Tahun 1974 tertanggal 2 Januari 1974.

Wasit Alwi memberi gambaran bahwa pengundangan tentang hukum perkawinan itu sama dengan produk hukum Islam lainnya, yang berasal dari ijtihâd jamẩi umat Islam bersama Pemerintah, yang tentunya berlandaskan Alquran dan Sunnah Rasul. Oleh karenanya, mengikuti aturan di dalam UU itu sama dengan menaati Allah, Rasul dan ulîl amri (pemerintah), seperti yang diperintahkan Allah dalam Q.s. al-Nisa' [4] ayat 59. Akan tetapi jika sebuah aturan hukum hanya dilahirkan dari ijtihâd para ilmuan saja (ulama), maka ia berfungsi tidak mengikat dan hanya dapat digunakan sebagai pedoman semata.

Sikap pembelaan atas UU perkawinan dari para akademisi Islam melalui berbagai pendekatan keilmuan seperti yang dilakukan oleh Wasit Alwi di atas, ternyata berdampak positif di masyarakat dalam memberi pamahaman kepada umat akan adanya fikih Indonesia. Dan dalam menyelesaikan sengketa rumah tangga, diundangkan UU No. 7 tahun 1989 tentang Peradilan Agama. Akan tetapi dalam tataran implementasi, ternyata begitu banyak para hakim yang merasa kesulitan dalam mengambil

${ }^{19}$ Sajuti Thalib, Receptio A Contrario Hubungan Hukum Adat dengan Hukum Islam, 4th ed. (Jakarta: Bina Aksara, 1985), h. 13.

${ }^{20}$ Neng Djubaedah, Pornografi dan Pornoaksi Ditinjau dari Hukum Islam: Edisi Revisi, 3rd ed. (Jakarta: Prenada, 2009), h. 78-82. 
keputusan hukum akibat beragamnya khazahan keilmuan fikih Islam, maka dihadirkanlah ketentuan hukum di dalamnya melalui Inpres No. 1 tahun 1991 tentang KHI.

Tahir Azhary menjelaskan tentang fungsi KHI dengan membaginya pada dua poin penting, yakni; (1) bahwa dengan lahirnya KHI, para hakim agama dapat dengan mudah dan sangat praktis merujuk KHI, khususnya bagi mereka yang tidak dapat membaca kitab kuning; (2) lahirnya KHI adalah sebagai wujud kontekstualisasi hukum Islam, sebab apa yang ada dalam kitab-kitab konvensional banyak yang sudah tidak relevan dengan tuntutan sekarang. ${ }^{21}$ Adapun sumber utama rumusan KHI adalah:

a. Hukum produk legislatif yang telah tertuang dalam perundangundangan dan peraturan lainnya, seperti UU No. 22 Tahun 1946 jo UU No. 32 Tahun 1954, UU No. 1 Tahun 1974 jo PP No. 9 Tahun 1975, UU No. 7 Tahun 1989 dan PP No. 22 Tahun 1977.

b. Yurisprudensi dalam lingkungan Peradilan Agama, terutama mengenai hukum waris dengan dukungan pengalaman tafsir hukum.

c. Produk eksplanasi ajaran Islam melalui kajian hukum oleh Perguruan Tinggi Islam (IAIN).

d. Pendapat ahli hukum Islam Indonesia.

e. Hasil studi banding ke Maroko, Turki dan Mesir.

f. Pendapat dan pandangan yang hidup pada saat lokakarya alim ulama tanggal 2-6 September 1988. ${ }^{22}$

\section{Era Reformasi}

Pada era ini, ada dua aspek semangat pembaruan hukum keluarga yang muncul. Pertama, mengangkat isu penghapusan atau revisi atas

${ }^{21}$ Tahir Azhary, "Kompilasi Hukum Islam Sebagai Alternatif: Suatu Analisis Sumber-Sumber Hukum Islam,” Mimbar Hukum 2, no. 4 (1991): 16.

${ }^{22}$ Khoiruddin Nasution, Hukum Perdata (Keluarga) Islam Indonesia dan Perbandingan Hukum Perkawinan di Dunia Muslim: Studi Sejarah, Metode Pembaruan, san Materi \& Status Perempuan dalam Hukum Perkawinan/Keluarga Islam (Yogyakarta: Fakultas Syariah Universitas Islam Negeri, 2009), h. 58-59. 
aturan hukum perkawinan, khususnya PP No. 10 tahun 1983 di tahun 1999-2000. Setidaknya ada lima kelompok yang akhirnya muncul sebagai respon dari isu tersebut:

a. Kelompok yang menghendaki penghapusan PP No. 10 tahun 1983 dan membolehkan poligami sesuai pendapat ulama konvensional. Alasan lainnya adalah, karena menurut mereka jumlah wanita lebih banyak dari jumlah laki-laki, maka poligami dapat menjadi solusi dengan syarat suami mampu berlaku adil.

b. Kelompok yang menghendaki PP ini dihapus dengan alasan poligami adalah urusan pribadi yang tidak perlu diatur negara.

c. Kelompok yang menghendaki PP ini dicabut, dengan alasan bahwa PP ini terbukti tidak mampu melindungi wanita.

d. Menghendaki dicabut, dengan alasan PP No. 10 tahun 1983 bersifat diskriminatif.

e. Pendapat mayoritas, di mana PP No. 10 tahun 1983 perlu dipertahankan dengan direvisi. Menurut kelompok ini PP tersebut dipercaya dapat menahan laju perkawinan poligami dikalangan PNS, jika lantas pengkhususan aturan ini terhadap PNS, karena PNS diharapkan menjadi garda depan pemersatu dan teladan bagi keluarga, umumnya masyarakat Indonesia. ${ }^{23}$

Setelah cukup lama pembicaraan tentang PP 10 di atas tidak lagi dibicarakan secara intensif, tiba-tiba di tahun 2006 Pemerintah melakukan aksi amandemen atas UU No. 7 Tahun 1989 dengan memberlakukan UU No. 3 Tahun 2006 yang memberikan otoritas dan status lebih luas kepada Pengadilan Agama. Dengan diberlakukannya UU baru tersebut, maka lahan garapan Pengadilan Agama bertambah pada tiga bidang, yakni zakat, infaq dan ekonomi syariah.

Selain itu, ternyata Pemerintah juga sedang mempersiapkan aksi lainnya dengan membentuk Tim Pengarusutamaan Gender (PUG) sebagai perumus UU Hukum Keluarga baru yang dapat merevisi UU No. 1 tahun 1974 di masa Presiden Megawati. Tim ini bekerja langsung di

${ }^{23}$ Khoiruddin Nasution, Hukum Perdata (Keluarga) Islam Indonesia dan Perbandingan Hukum Perkawinan di Dunia Muslim, h. 73-74. 
bawah pengawasan dan mandat dari Menteri Agama saat itu, dengan objek penelitian berada pada isi KHI. Oleh karena draft rumusan UU tersebut terlihat sangat bertentang dengan KHI maka draft itu kemudian dikenal dengan nama Counter Legal Draft-Kompilasi Hukum Islam (selanjutnya disebut CLD-KHI), yang berisi 116 pasal dalam Buku I tentang Perkawinan, 8 bab dan 42 pasal dalam Buku II tentang Kewarisan, dan 5 bab 20 pasal dalam Buku III tentang Perwakafan.

Perjalanan CLD-KHI ternyata mengalami perlawanan yang cukup sengit—sebagaimana yang telah dijelaskan pada sub bab sebelumnyatermasuk dari kalangan ulama dan akademisi, maka Menteri Agama yang baru berjalan beberapa hari langsung membuat surat keputusan untuk membubarkan tim kerja itu ${ }^{24}$ karena dianggap liberal dan bertentangan dengan syariat Islam.

Setelah kegagalan CLD-KHI menjadi UU, advokasi masalah hukum keluarga akhirnya dilakukan melalui pengajuan materi hukum pada pasal-pasal UU No. 1 Tahun 1974 di Mahkamah Konstitusi. Salah satunya adalah Putusan MK Nomor 46/PUU-VIII/2010, Tanggal 13 Februari 2012, atas permohonan dari Aisyah Mochtar alias Machica binti Mochtar Ibrahim dan Muhammad Iqbal Ramadhan bin Moerdiono untuk mengajukan uji materil terhadap Pasal 2 ayat (2) dan Pasal 43 ayat (1) Undang-Undang Nomor 1 Tahun 1974 tentang Perkawinan, dan dalam perjalannya, MK hanya mengabulkan sebagian dari permohonan Pemohon tersebut, yakni pada Pasal 43 ayat (1), di hari Jumat 17 Februari 2012. ${ }^{25}$

${ }^{24}$ Lihat "Surat Menteri Agama Nomor MA/274/2004 Tentang Counter Legal Draft KHI," Oktober 2004. jo. "Surat Menteri Agama RI Nomor MA/271/2004 Tentang Teguran," tanggal Oktober 2004.

${ }^{25}$ Putusan MK tersebut menjadi bahan kajian di berbagai perguruan tinggi. Di antara kajian tersebut adalah Mukhamad Farid, "Interpretasi Hakim Tentang Anak di Luar Kawin Pasca Putusan Mahkamah Konstitusi Nomor 46/PUU-VIII/2010 Tentang Pengujian UU Nomor 1 Tahun 1974 Tentang Perkawinan (Studi di Pengadilan Agama Purwokerto)," Jurnal Idea Hukum, Magister Hukum Fakultas Hukum Universitas Jenderal Soedirman I, no. 2 (Oktober 2015): 123-133.; Anik Tri Haryani and Tiara Oliviarizky Toersina, "Hak Keperdataan Anak Luar Kawin Pasca Judicial Review Undang-Undang Nomor 1 Tahun 1974 dalam Putusan Mahkamah Konstitusi Nomor 46/PUU-VIII/2010," Sosial 14, no. 2 (September 2013): 12-23.; Erlina, "Access To Justice 'Anak di Luar Perkawinan' (Analisis Putusan Mahkamah Konstitusi Nomor 46/PUU-VIII/ 2010 Tentang Pengujian Pencatatan Perkawinan dan Status Hukum Anak 


\section{Memaknai Benturan Pemikiran Pasca Reformasi}

Sejatinya benturan pemikiran dijadikan sebagai modal pembaruan (liyatafaqqahu fî al-dîn), memperkaya khazanah keilmuan Islam di Indonesia, sehingga memberi manfaat yang optimal bagi semesta alam. Konsep utamanya adalah "Bhineka Tunggal Ika", meskipun berbeda namun tetap satu jua, agree in disagreement, setuju dalam perbedaan yang ada. Perbedaan hendaknya menjadi rahmat bagi siapapun yang berpikir, karena mampu memberi pemahaman yang mendalam kepada mereka, sehingga umat mampu bersatu dalam beragam perbedaan dengan konsep besar hukum Islam, yakni jalb al-mashâlih wa dar'u al-mafâsid, menghadirkan kemaslahatan dan mengcounter kerusakan.

Teks agama yang dianggap sakral dan absolut baik bentuk dan isinya oleh kelompok fundamentalis-konservatif Islam, namun bertolak belakang dengan kelompok liberalisme Islam di mana teks tidak boleh mengkungkung kebebasan berpikir manusia. Sehingga menganggap akal sama sucinya dengan wahyu Tuhan yang suci, dan akal memiliki hak yang besar dalam melakukan interpretasi yang luas atas kehendak Tuhan tersebut. Sebagai jalan rekonsiliasi antar keduanya adalah melalui pemahaman yang mendalam tentang keberadaan politik hukum sebagai mediator.

Maksud dari ungkapan di atas adalah antara Islam dan negara memiliki hubungan yang harus selalu seiring-sejalan dari awal hingga akhirnya, karena-sebagaimana penjelasan Yudian K. Wahyudi ${ }^{26}$ -

Yang Dilahirkan dari Perkawinan Yang Tidak Tercatat Undang-Undang Nomor 1 Tahun 1974 Tentang Perkawinan)," Jurnal Konstitusi PSHK, Universitas Islam Indonesia Kerjasama Dengan Mahkamah Konstitusi Republik Indonesia I, no. 1 (November 2008): 33-58. Ida Martinelli, "Hukum Anak Luar Kawin Pasca Putusan Mahkamah Konstitusi Nomor 46/PUU-VIII/2010," De Lega Lata I, no. 2 (July 2016): 308-328. I Gede Pasek Pramana, “Konsekuensi Yuridis Putusan Makamah Konstitusi No. 46/PUU-VIII/2010 Terhadap Kedudukan Anak Astra dalam Hukum Adat Bali," Jurnal Magister Hukum Udayana 7, no. 3 (2014): 411-422. Suphia, "Hubungan Keperdataan Anak Luar Kawin Pasca Putusan Mahkamah Konstitusi No. 46/PUU-VIII/2010," Jurnal Rechtens 4, no. 2 (Desember 2015): 1-14. Habib Shulton Asnawi, "Dasar Hukum Hakim Mahkamah Konstitusi dalam Memutuskan Perkara No. 46/PUUVIII/2010 Tentang Status Hukum Anak di Luar Nikah (Perspektif Hukum Islam dan Hak Asasi Manusia)," Fikri 1, no. 1 (June 2016): 45-78.

${ }^{26}$ Faisal, "Penerapan Hukum Takzir dalam Hukum Positif: Analisis Atas Ketentuan Pidana dalam UU. No. 23 Tahun 2011 Tentang Pengelolaan Zakat” n.d., 17-19. Disampaikan Pada Upacara Pengukuhan Guru Besar Prof. Dr. Faisal, SH., MH., di IAIN Raden Intan Lampung. 
ada lima pasangan karakteristik hukum Islam. Pertama, hukum Islam bersifat Ilahi sekaligus wadh'iy (manusiawi; positif, sekuler). Kedua, hukum Islam bersifat absolut tetapi sekaligus relatif. Ketiga, hukum Islam bersifat universal tapi juga sekaligus lokal. Keempat, hukum Islam bersifat abadi tetapi sekaligus temporal. Kelima, hukum Islam bersifat harfiyyah sekaligus mánawiyyah. Oleh karena pasangan hukum Islam yang saling mengisi di atas, maka model hubungan yang harus selalu dijalin dalam melakukan pembangunan hukum antara Islam dan negara adalah dengan cara paradigma simbiotik, yakni hubungan yang bersifat timbal balik dan saling memerlukan dan mengisi, di mana agama memerlukan negara untuk dapat berkembang, dan negara membutuhkan agama dalam melakukan bimbingan moral dan etika. ${ }^{27}$

Perspektif moderasi yang menyatukan antara idealitas dan kenyataan lapangan, seperti yang dibangun di atas, akan mampu meyakinkan bagi setiap kelompok tentang keniscayaan dari pembaruan hukum Islam di Indonesia, khususnya hukum keluarga. Adapun cara (al-tartîb) pembaruan dapat dilihat dari penjelasan Fathurrahman Djamil. ${ }^{28}$ Pertama, usaha memilih berbagai sistem hukum (the eclectic expedient). Kedua, usaha pembaruan di bidang hukum acara (the procedural exepedient). Ketiga, usaha pembaruan di bidang administrasi (the exepedient of administrative orders). Keempat, usaha memperbarui putusan yang mempunyai kekuatan hukum (the exepedient of reform by judicial decision).

Proses yang dibangun secara tertib di atas, mendahulukan kajian awalnya pada kerangka metodologis (manhâjiyyah) berupa telaah atas teks, konteks dan substansi dari itu semua. Artinya, ketika berbicara tentang teks, maka sudut pandang yang universal dan visioner menjadi

Lihat juga Yudian Wahyudi, Is Islamic Law Secular? A Critical Study of Hasan Hanafi's Legal Philisophy (Yogyakarta: Pesantrean Nawesea Press, 2007). Maqasid Asy-Syariah dalam Pergumulan Politik: Berfilsafat Hukum Islam dari Harvard ke Sunan Kalijaga (Yogyakarta: Pesantrean Nawesea Press, 2007), h. 27-28.

${ }^{27}$ Lihat Abd. Salam Arief, "Politik Islam Antara Aqidah dan Kekuasaan Negara", dalam A. Maftuh Abegebriel and etc, Negara Tuhan: The Thematic Encyclopedia (Yogyakarta: SR-Ins Publishing, 2004), h. 110-111.

${ }^{28}$ Fathurrahman Djamil, "Reaktualisasi dan Legislasi Hukum Islam," Juridiksi I, no. I (1996): 13-14. Lihat juga Faisal, Pluralisme Hukum di Indonesia: Kekuatan, Kelemahan, Peluang dan Ancaman (Yogyakarta: Maghza, 2012), h. 75. 
acuan, sedangkan tentang konteks, sudut pandang pembaca berada pada sekat-sekat lokal manusianya, seperti budaya, agama, dan ras yang terangkum dalam pluralitas. Berdasarka hal tersebut, kemudian dilakukan "penggodokan" akademis dan ilmiah sehingga mampu melahirkan substansi dari keberadaan teks di dunia ini bagi umat manusia.

Argumentasi yang mensinergikan antara gerak teks dan konteks dalam menghadapi pluralisme hukum dan budaya melalui jalur politik hukum sehingga menghadirkan substansi, dapat disandarkan melalui perilaku dan kebijakan Rasulullah Muhammad Saw ketika berada di Madinah yang berhadapan dengan masyarakat heterogen dan plural. Produknya yang hingga kini masih menjadi primadona kajian para peneliti dunia dalam menggambarkan negara, demokrasi, dan HAM model Islam, adalah Piagam Madinah. Heterogenitas dan pluralitas yang ada di Madinah menyangkut agama, suku, adat, dan ras. Semua berkumpul menjadi satu dalam keramahan Islam berdasarkan konstitusi Piagam Madinah yang menjadi rujukan.

Dalam hal pluralitas agama, Al-Burey mencatat bahwa Islam mengakui kebebasan beragama tidak hanya pada tataran normatif namun juga dalam praktik kehidupan. ${ }^{29}$ Lebih rinci, Katimin menjelaskan, Piagam Madinah memberikan landasan akan jaminan otonom bagi kelompok agama menjalankan agamanya, adat tradisi serta persamaan hak bagi semua orang, dengan berisikan penekanannya pada demokrasi dan konsensus, bukan pada tekanan dan paksaan. ${ }^{30}$ Oleh karenanya sebagai konstitusi negara, ketetapan di dalam Piagam Madinah mengandung makna dan fungsi strategis, karena kebebasan dijamin secara konstitusional. ${ }^{31}$

Analogi yang dapat dibangun melalui rujukan historis di atas adalah, antara Islam dan negara memang tidak akan pernah dapat dipisahkan,

${ }^{29}$ Muhammad A. al-Buraey, Administrative Development or Islam Landasan Alternatif Administrasi Pembangunan, trans. Achmad Nashir Budiman (Jakarta: Rajawali, 1986), h. 83.

${ }^{30}$ Katimin, "Dimensi Teologis Pemikiran Politik Islam", dalam Hasan Asari and Amroeni Drajat, Antologi Kajian Islam (Bandung: Cita Pustaka Media, 2004), h. 41.

${ }^{31}$ Rahmad Asril Pohan, Toleransi Inklusif: Menapak Jejak Sejarah Kebebasan Beragama dalam Piagam Madinah (Yogyakarta: Kaukaba, 2014), h. 171. 
ia akan selalu berparadigma simbiotik hingga kapanpun. Dan idealisme akan selalu dipegang hingga kapanpun juga, karena dijaga oleh konstitusi. Indonesia adalah negara yang secara sosiologis sama dengan Madinah yang heterogen dan plural, bahkan lebih plural dari Madinah, maka dalam menyambung komunikasi yang tersendat oleh berbagai kepentingan kelompok hanya dapat dilakukan melalui kebijakan negara melalui politik hukumnya. Inilah solusi singkat dalam meramu perbedaan prinsip antara liberalisme dan fundamentalisme Islam di Indonesia sehingga mampu saling memberi manfaat dalam melakukan pembangunan hukum di Indonesia.

\section{Penutup}

Gerakan pembaruan hukum keluarga era orde lama dilakukan oleh para ulama yang duduk di parlemen dengan melahirkan UU No. 22 Tahun 1946 hingga lahir UU No. 32 Tahun 1954 sebagai acuan atas pemberlakuan UU No. 22 Tahun 1946 untuk seluruh wilayah Indonesia. Namun perdebatan demi perdebatan terus bermunculan hingga lahirnya Dekrit Presiden pada tanggal 5 Juli 1959, dan seluruh proses politik terhenti dengan sendirinya.

Gerakan pembaruan hukum keluarga era orde meskipun mengalami perdebatan yang panjang hingga lahirlah UU Perkawinan pertama di Indonesia ditandatangani oleh Presiden dalam Lembaran Negara No. 1 Tahun 1974 tertanggal 2 Januari 1974. Pada 90-an, semangat untuk perbaikan hukum keluarga terus bergulir hingga lahirlah Kompilasi Hukum Islam (KHI) sebagai materi hukum yang digunakan oleh Pengadilan Agama dalam menyelesaikan problem hukum keluarga Islam di Indonesia.

Gerakan pembaruan hukum keluarga di era reformasi berjalan melalui dua jalur, yakni judisial review pasal-pasal di dalam UU Perkawinan ke Mahkamah Konstitusi dan gerakapan pembaruan jalur eksekutif melalui Pengarusutamaan Gender (PUG) Departemen Agama RI dengan melahirkan Counter Legal Draft-Kompilasi Hukum Islam (selanjutnya disebut CLD-KHI), yang berisi 116 pasal dalam Buku I tentang Perkawinan, 8 bab dan 42 pasal dalam Buku II tentang Kewarisan, 
dan 5 bab 20 pasal dalam Buku III tentang Perwakafan. Gerakan PUG mendapatkan penolakan dari berbagai lini karena dianggap liberal, hingga Menteri Agama membuat surat keputusan untuk membubarkan tim kerja tersebut.

\section{Pustaka Acuan}

Abegebriel, A. Maftuh and etc. Negara Tuhan: The Thematic Encyclopedia. Yogyakarta: SR-Ins Publishing, 2004.

Arief. Abd. Salam. "Politik Islam Antara Aqidah dan Kekuasaan Negara," n.d.

"Amanat Presiden No. R.02/P.U/VII/1973 Perihal RUU Tentang Perkawinan," July 31, 1973.

Asnawi. Habib Shulton. "Dasar Hukum Hakim Mahkamah Konstitusi dalam Memutuskan Perkara No. 46/PUUVIII/2010 Tentang Status Hukum Anak di Luar Nikah (Perspektif Hukum Islam dan Hak Asasi Manusia)." Fikri 1, no. 1 (June 2016): 45-78.

Asari, Hasan dan Amroeni Drajat. Antologi Kajian Islam. Bandung: Cita Pustaka Media, 2004.

Azhary, Tahir. "Kompilasi Hukum Islam Sebagai Alternatif: Suatu Analisis Sumber-Sumber Hukum Islam.” Mimbar Hukum II, no. 4 (1991): 16.

Al-Buraey. Muhammad A. Administrative Development or Islam Landasan Alternatif Administrasi Pembangunan. Translated by Achmad Nashir Budiman. Jakarta: Rajawali, 1986.

Al Arif, M. Yasin. Politik Hukum Calon Tunggal dalam Putusan Mahkamah Konstitusi dan Implikasinya Terhadap SIstem Pilkada Serentak, Jurnal Yuridis 3, No. 2, Desember (2016).

Djamil, Fathurrahman. "Reaktualisasi dan Legislasi Hukum Islam." Juridiksi I, no. I (1996): 13-14.

Djubaedah, Neng. Pornografi dan Pornoaksi Ditinjau dari Hukum Islam: Edisi Revisi. 3rd ed. Jakarta: Prenada, 2009.

Erwinsyahbana, Tengku. "Perspektif Hukum Perkawinan Antar Agama yang Berkeadilan Dikaitkan dengan Politik Hukum Perkawinan 
Indonesia dalam Rangka Pembangunan Hukum Keluarga Nasional.” Indonesian Journal of Dialectics 2, no. 2 (2012).

, "Sistem hukum perkawinan pada Negara hukum berdasarkan pancasila.” jurnal ilmu bukum 3, no. 01 (2013).

Erlina. “Access To Justice 'Anak di Luar Perkawinan' (Analisis Putusan Mahkamah Konstitusi Nomor 46/PUU-VIII/ 2010 Tentang Pengujian Pencatatan Perkawinan dan Status Hukum Anak Yang Dilahirkan dari Perkawinan Yang Tidak Tercatat Undang-Undang Nomor 1 Tahun 1974 Tentang Perkawinan)." Jurnal Konstitusi PSHK, Universitas Islam Indonesia Kerjasama dengan Mabkamah Konstitusi Republik Indonesia I, no. 1 (November 2008): 33-58.

Faisal. "Penerapan Hukum Takzir dalam Hukum Positif: Analisis Atas Ketentuan Pidana dalam UU. No. 23 Tahun 2011 Tentang Pengelolaan Zakat".

, Pluralisme Hukum di Indonesia: Kekuatan, Kelemahan, Peluang dan Ancaman. Yogyakarta: Maghza, 2012.

Farid, Mukhamad. "Interpretasi Hakim Tentang Anak di Luar Kawin Pasca Putusan Mahkamah Konstitusi Nomor 46/PUU-VIII/2010 Tentang Pengujian UU Nomor 1 Tahun 1974 Tentang Perkawinan (Studi di Pengadilan Agama Purwokerto)." Jurnal Idea Hukum, Magister Hukum Fakultas Hukum Universitas Jenderal Soedirman I, no. 2 (Oktober 2015): 123-33.

Hasbi, Muhammad. "Studi Komparatif Antara Hukum Islam dan Hukum Positif Undang-Undang Perkawinan No 1 Tahun 1974 Tentang Batas Ketaatan Isteri Terhadap Suami.” PhD diss., Universitas Muhammadiyah Surakarta, 2013.

Haryani, Anik Tri and Tiara Oliviarizky Toersina. "Hak Keperdataan Anak Luar Kawin Pasca Judicial Review Undang-Undang Nomor 1 Tahun 1974 Dalam Putusan Mahkamah Konstitusi Nomor 46/ PUU-VIII/2010.” Sosial 14, no. 2 (September 2013): 12-23.

Hidayatullah, Bagus Anwar. "Politik Hukum Sistem Pemilu Legislatif dan Presiden Tahun 2009 dan 2014 dalam Putusan Mahkamah Konstitusi”, Jurnal Hukum Ius Quia Iustum 21, No. 4, (Oktober 
2014), Yogyakarta: Fakultas Hukum Universitas Islam Indonesia, Himsyah, Fatroyah Asr. "Batas Usia Perkawinan Menurut pasal 7 UndangUndang no. 1 tahun 1974 Perspektif Undang-Undang No. 23 Tahun 2002 Tentang Perlindungan Anak.” PhD diss., Universitas Islam Negeri Maulana Malik Ibrahim Malang, 2011.

Jafizham, T. Persentuhan Hukum di Indonesia dengan Hukum Perkawinan Islam. Medan: Mestika, 1977.

Martinelli, Ida. "Hukum Anak Luar Kawin Pasca Putusan Mahkamah Konstitusi Nomor 46/PUU-VIII/2010.” De Lega Lata I, no. 2 (July 2016): 308-28.

Muhammad bin Hibban. Shahih Ibnu Hibban. Vol. 9. Bayrût: Mu`assasah al-Rasalah, 1993.

Nasution, Khoiruddin. Hukum Perdata (Keluarga) Islam Indonesia dan Perbandingan Hukum Perkawinan di Dunia Muslim: Studi Sejarah, Metode Pembaruan, dan Materi \& Status Perempuan dalam Hukum Perkawinan/Keluarga Islam. Yogyakarta: Fakultas Syariah Universitas Islam Negeri, 2009.

Operasi, April 14, 1969.

Pramana, I Gede Pasek. "Konsekuensi Yuridis Putusan Makamah Konstitusi No. 46/PUU-VIII/2010 Terhadap Kedudukan Anak Astra dalam Hukum Adat Bali." Jurnal Magister Hukum Udayana 7, no. 3 (2014): 411-22.

Prins, J. Hukum Perkawinan di Indonesia. Translated by G.A. Ticoalu. Jakarta: Ghalia Indonesia, 1982.

Pohan, Rahmad Asril. Toleransi Inklusif: Menapak Jejak Sejarah Kebebasan Beragama dalam Piagam Madinah. Yogyakarta: Kaukaba, 2014.

Prodjodikoro, Wirjono. Hukum Perkawinan di Indonesia. 8th ed. Bandung: Sumur, 1984.

Rahayu, Ninik. "Politik Hukum Itsbat Nikah.” Musãwa Jurnal Studi Gender dan Islam 12, no. 2 (2016): 279-294.

Rasjadi. H. M. Kasus RUU Perkawinan dalam Hubungan Islam dan Kristen. Jakarta: Bulan Bintang, 1974. 
Sanger, Juliana Pretty. "Akibat Hukum Perkawinan Yang Sah Didasarkan Pada Pasal 2 UU. Nomor 1 Tahun 1974 Tentang Perkawinan.” Lex Administratum 3, no. 6 (2015).

Sidharta, P. H. "Undang-Undang Perkawinan Ditinjau dari Segi Hukum Antar Tata Hukum pada Dewasa Ini.” Jurnal Hukum \& Pembangunan 22, no. 4 (1992): 334-353.

Soewondo, Nani. Kedudukan Wanita Indonesia dalam Hukum dan Masyarakat. 2nd ed. Jakarta: Timun Mas, 1968.

Sularno, M. "Dinamika Hukum Islam Bidang Keluarga di Indonesia." AlMawarid 18 (2008).

Surat Menteri Agama Nomor MA/274/2004 Tentang Counter Legal Draft KHI, Oktober 2004.

Surat Menteri Agama RI Nomor MA/271/2004 Tentang Teguran,” tanggal Oktober 2004.

Suphia. "Hubungan Keperdataan Anak Luar Kawin Pasca Putusan Mahkamah Konstitusi No. 46/PUU-VIII/2010.” Jurnal Rechtens 4, no. 2 (Desember 2015): 1-14.

Syahuri, Taufiqurrohman. Legislasi Hukum Perkawinan di Indonesia: ProSosroatmodjo, Asro dan A. Wasit Aulawi. Hukum Perkawinan di Indonesia. Jakarta: Bulan Bintang, 1978.

Thalib, Sajuti. Receptio A Contrario Hubungan Hukum Adat dengan Hukum Islam. 4th ed. Jakarta: Bina Aksara, 1985.

Wahid, Marzuki. "Pembaruan Hukum Keluarga Islam di Indonesia Paska Orde Baru: Studi Politik Hukum atas Counter Legal Draft Kompilasi Hukum Islam [Renewal of Islamic Family Law in Post at New Order Indonesia: Legal-Political Study On Counter Legal Draft of the Compilation of Islamic Law]." In 4th Annual Islamic Studies Postgraduate Conference, Melbourne, pp. 17-18. 2008. , "Counter Legal Draft Kompilasi Hukum Islam (CLD-KHI) dalam Perspektif Politik Hukum di Indonesia." In 4th Annual Islamic Studies Postgraduate Conference, The University of Melbourne, pp. 17-18. 2008. 
Wahyudi, Yudian. Is Islamic Law Secular? A Critical Study of Hasan Hanafi's Legal Philisophy. Yogyakarta: Pesantrean Nawesea Press, 2007. , Maqasid Asy-Syariah dalam Pergumulan Politik: Berfilsafat Hukum Islam dari Harvard ke Sunan Kalijaga. Yogyakarta: Pesantrean Nawesea Press, 2007. 